\title{
Responsibility Parking Service Business to The Protection Of Consumer Of The Parking Services in Makassar
}

\author{
Andika Prawira Buana, Aan Aswari, Muh. Fachri Said, Muhammad Ya'rif Arifin \\ Faculty of Law, Universitas Muslim Indonesia \\ andika.prawira@umi.ac.id
}

\begin{abstract}
The development of dynamic human behavior will lead to more complex contractual relationships. A contractual relationship that occurs must necessarily be accompanied by certainty and legal protection for each party. Existing regulations should serve as guidelines for contractual relationships. Parking business practitioners and parking service users must understand and know the rights and obligations of each. The form of liability which must be fulfilled by each party shall be adhered to in order to create a good contractual relationship and the fulfillment of rights and obligations based on the prevailing laws and regulations. This research is research with qualitative type with the socio-juridical approach. This study responded the ineffectiveness of the accountability of parking service business actors (PD Parkir Makassar Raya) to the consumer protection of parking service users because there is still a standard clause on the parking ticket. Makassar City Local Government needs to provide direct supervision on policies issued by PD Parkir Makassar Raya and revise the Local Regulation on Parking Management in order to be relevant to the provisions of the higher Legislation (UUPK). Parking service users are also required to increase legal awareness to know what rights and obligations of service users and parking service business actors.
\end{abstract}

Keywords: responsibility of business actors, consumer protection, parking service

\section{INTRODUCTION}

The consumer is any user of goods and/or services available in society, whether for self-interest, family, other people, or other living things and not for trading. Generally a product before reaching the hands of consumers first through a long distribution process, ranging from producers, distributors, agents, retailers, until finally reached the hands of consumers, so that in the economic field is known two types of consumers, namely end consumers and consumers between. The final consumer is the end user or beneficiary of a product, while the intermediate consumer is the consumer who uses a product as part of the production process of another product. The consumer referred to in Law Number 8 the Year 1999 on Consumer Protection is the ultimate Consumer. ${ }^{1}$

Based on Article 4 of Law Number 8 of the Year 1999 regarding Consumer Protection, Consumer Right is as follows:

\footnotetext{
${ }^{1}$ Wibowo Tunardy, http://www.jurnalhukum.com/pengertian-konsumen/, in access date May 2, 2017 at 10.30 WITA.
} 
a) the right to comfort, security and safety in the consolidation of goods and/or services;

b) the right to choose goods and/or services and obtain the goods and/or services in accordance with the exchange rate and the conditions and promised warranties;

c) the right to true, clear, and truthful information about the condition and guarantee of goods and/or services;

d) the right to be heard of his opinions and complaints on the goods and/or services used;

e) the right to appropriate advocacy, protection, and dispute resolution efforts;

f) the right to counsel and education of consumers;

g) the right to be treated or served properly and honestly and not discriminatively;

h) the right to compensation, indemnification and/or reimbursement, if the goods and/or services received are not in accordance with the agreement or not as they should;

i) rights set forth in the provisions of other laws and regulations.

Then, pursuant to Article 5 of Law Number 8 of the Year 1999 concerning Consumer Protection, Consumer Liability is as follows:

a) read or follow directions for information and procedures on the use or use of goods and/or services, for security and safety;

b) have good faith in the purchase of goods and/or services;

c) pay according to the agreed exchange rate;

d) to follow appropriate dispute resolution measures for consumer protection.

Based on the above description, the rights and obligations of consumers must be fulfilled based on Law No. 8 of 1999 on Consumer Protection without exception.

Article 1 number 3 of Law Number 8 Year 1999 regarding Consumer Protection states that business actor is any individual or business entity, whether in the form of a legal entity or non-legal entity established and domiciled or conducting activities within the territory of the Republic of Indonesia, either alone or together through agreements to conduct business activities in various economic fields.

Based on Article 6 of Law Number 8 of the Year 1999 concerning Consumer Protection, Business Actor Rights are as follows:

a. the right to receive payments in accordance with the agreement on the conditions and exchange rates of goods and/or services traded;

b. the right to legal protection from misconducted consumer acts;

c. the right to self-defense should be appropriate in the settlement of consumer disputes laws; 
d. the right to the rehabilitation of a good name if it is legally proven that the consumer's loss is not attributable to the goods and/or services being traded;

e. rights set forth in the provisions of other laws and regulations.

b) Then, pursuant to Article 7 of Law Number 8 the Year 1999 concerning Consumer Protection, the Obligations of Business Actors are as follows:

c) having good faith in doing business;

d) provide true, clear and honest information about the condition and guarantee of goods and/or services and provide explanations of the use, repair, and maintenance;

e) treat or serve consumers properly and honestly and not discriminatively;

f) to guarantee the quality of goods and/or services produced and/or traded under the provisions of the applicable quality standards of goods and/or services;

g) provide consumers with the opportunity to test, and/or try certain goods and/or services and provide guarantees and/or warranties on manufactured and/or traded goods;

h) compensate, indemnify and/or reimburse for losses arising from the use, use and utilization of traded goods and/or services;

i) compensate, indemnify and/or reimburse if the goods and/or services received or utilized are not in accordance with the agreement.

Based on the above description, the rights and obligations of business actors must also be fulfilled based on Law No. 8 of 1999 on Consumer Protection without exception.

Article 18 of Law Number 8 the Year 1999 concerning Consumer Protection, Business actors in offering goods and/or services intended for trading are prohibited to make or include a standard clause in every document and/or agreement if:

a) declare the transfer of responsibilities of business actors;

b) declare that the business actor has the right to refuse the redemption of goods purchased by the consumer;

c) declare that the entrepreneur is entitled to refuse the redemption of money paid for goods and/or services purchased by the consumer;

d) declare the authorization of the consumer to the business actor either directly or indirectly to perform any unilateral action relating to the goods purchased by the consumer in installments;

e) regulates the proof of loss of usefulness of goods or the utilization of services purchased by consumers; 
f) to grant the businessmen the right to reduce the benefits of services or reduce the assets of consumers who become the object of sale and purchase of services;

g) declare the consumer's compliance with the regulations in the form of new rules, additions, further and/or subsequent changes made unilaterally by the business actor in the period when the consumer utilizes the services he/she purchases;

h) declare that the consumer authorizes the business actor to impose mortgage rights, the right to gad.

Furthermore in the provisions are also set :

Business actors are prohibited to include a standard clause whose location or form is difficult to see or can not be read clearly, or whose disclosure is difficult to understand.

Any standard clause established by the business actor on documents or agreements that meet the provisions referred to in paragraphs 1 and 2 shall be declared null and void. And Business actors shall comply with the standard clauses contrary to this Law. ${ }^{2}$

Law No. 8/1999 on Consumer Protection in Article 4 letter a provides that consumers are entitled to the convenience, safety and safety in consuming goods and/or services. For the sake of the realization of the parking service business actors or in this case the parking manager burden the consumer with parking service tariffs. ${ }^{3}$ However, security issues are still a major concern because consumers who experience loss of vehicles or supporting objects such as helmets and so on, in practice the parking manager is not responsible for the loss under the pretext of having included a clause on the parking ticket that reads "any form damage/loss is not the responsibility of the parking manager ". Law No. 8/1999 on Consumer Protection in Article 18 letter a confirms that business actors in offering goods and/or services intended for trading are prohibited to make or include a standard clause in every document and/or agreement if declared the transfer of responsibility of business actor. ${ }^{4}$ The parking clause is considered a standard clause because it is a form of transfer of responsibility from the parking manager. In the Civil Code, the act is a form of unlawful deed for causing harm to others under Articles 1365, 1366, and 1367 of the Civil Code.

a. Article 1365: "Any act that violates the law and brings harm to another person, obliges the person who caused the loss by his guilt to compensate the loss."

\footnotetext{
${ }^{2}$ Sari, Dwi Tyas Ratna. "Analisis Yuridis Perjanjian Baku Dalam Perjanjian Parkir Yang Dibuatoleh Pt Securindo Packtama Indonesia Di Surabaya." JURNAL NOVUM 1.1 (2013).

${ }^{3}$ Satuhu, Rachmanto. "Kendala Dinas Perhubungan dalam Mengawasi dan Memberi Pembinaan Bagi Pengelola Parkir untuk Mencegah Penggunaan Klausa Eksonerasi pada Karcis Parkir (Studi di Dinas Perhubungan Kota Malang)." Kumpulan Jurnal Mahasiswa Fakultas Hukum 1.6 (2013).

${ }^{4}$ Seran, Marcel, and Anna Maria Wahyu Setyowati. "Penggunaan Klausula Eksonerasi Dalam Perjanjian Dan Perlindungan Hukum Bagi Konsumen." Jurnal Hukum Pro Justitia 26.2 (2008).
} 
b. Article 1366: "Everyone is responsible, not only for the harm caused by the acts but also for the harm caused by his negligence or frivolity."

c. Article 1367: "A person shall be responsible not only for the loss caused by his own deeds but also for the harm caused by the acts of his dependents or due to the goods under his control."

From the Article contained in the Civil Code above, for the sake of the realization of legal certainty of the management of the parking lot can not release responsibility just like that, and the parking manager can be in civil litigation and allow the existence of criminal charges. Based on the background of the above problem, the researcher took the problem formulation such that became the focus of research is as follows: "How is the responsibility of parking service business actors to consumers parking service users?

\section{METHOD}

This research is research with qualitative type with socio juridical approach. This study uses primary and secondary data with data collection techniques of face-to-face interviews and questionnaire distribution. Primary data were analyzed based on qualitative descriptive and secondary data were analyzed based on quantitative descriptive in the form of frequency tabulation and percentage distribution with formula :

$$
\begin{aligned}
& \mathrm{P}=\frac{f}{n} \times 100 \% \\
& \mathrm{P}=\text { Percentage. } \\
& \mathrm{F}=\text { Frequency } \\
& \mathrm{N}=\text { Number of Sample }
\end{aligned}
$$

\section{ANALYSIS AND DISCUSSION}

\section{Responsibility of Parking Service Business Actor}

Loss of vehicles in the parking lot certainly does not become the desire of each owner. Of course this should be a special concern for parking service business actors as the party most responsible on the location of parking. Consumers as parking service users, of course felt that parked vehicles have secured the security of parking service business actors. In a field review the researchers found there were still parking service business actors who transferred the security responsibility to consumers. It is proven, in the location of the parking that became the location of this study still includes a standard clause which in Law no. 8 of 1999 on Consumer Protection in Article 18 clearly prohibits the inclusion of standard clauses by business actors as a form of transfer of responsibility. This illustrates 
that between the rule of law in its implementation has not fully provide legal protection for consumer parking service users. PD Parkir Makassar Raya as a parking service business actor who is one of the regional companies in Makassar City, basically has not applied the applicable law rules especially those related to the Consumer Protection Act. PD Parkir Makassar Raya still includes a standard clause on the parking ticket for 2017 budget year and transfer all responsibility to parking service user.

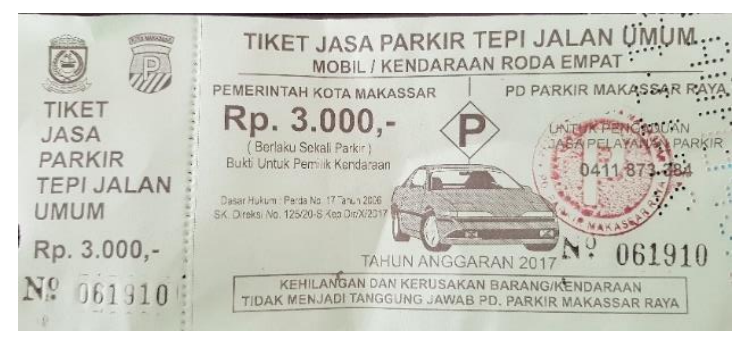

Figure 1. Display Parking Ticket PD Parkir Makassar Raya

In running its business, PD Parkir Makasar Raya imposes a fee to parking service user as business actor. At the expense of certainly raises the relationship as a form of rights and obligations for each party. The relationship between parking service business actors and consumers is actually the relationship between producers and consumers, where the producer position (PD Parkir Makassar Raya) is stronger because it sets the policies unilaterally. The relationship arising from such costs is not an engagement that obligates the consumer to share the losses of his nature. In Article 9 paragraph 1 UUPK clearly stated that the business actor is responsible to provide compensation for damage, pollution, and/or consumer loss due to consuming goods and/or services produced or traded.

The Supreme Court ruling, based on a petition for petition of 124/PPK/PDT/2007 filed by PT Securindo Packatama Indonesia (SPI) which administers Secure Parking. PT SPI requests a judgment on a cassation decision winning its consumer, Anny R Gultom to be exempt from compensation obligations. Unfortunately, the PK ruling made by 3 judges namely M Imron Anwari (the chairman of the panel of judges), East Manurung, Judge Nyak Pha corroborate the decision of Cassation that PT SPI must replace the lost vehicle. "With the ruling, the parking manager can no longer take shelter with a standard clause of transfer of responsibility that reads' any loss is not the responsibility of the parking manager. ${ }^{5}$ The decision of the Supreme Court must be a legal certainty and can be used as jurisprudence for all forms related to the dispute between parking service user and parking service ${ }^{5}$ M Ravii Marwan, http://news.gunadarma.ac.id/2017/07/mahkamah-agung-kehilangan-kendaraan-saat-parkir-
wajib-diganti-pengelola/, accessed on November 15, 2017 at 16:28 WITA. 
business actor, because the relevance of an information is also a concern, where information is diverse now can be made reference by anyone in making a deal. ${ }^{6}$

Legal awareness became the main demand for the community to dispute between parking service business actors and parking service users no longer occur. In the questionnaires, $62 \%$ of respondents answered not understanding what is meant by "standard clause" written on parking ticket.

\begin{tabular}{|c|c|c|c|}
\hline No. & Answer Category & Frequency & Percentage \\
\hline 1. & Yes & 19 & $38 \%$ \\
2. & No & 31 & $62 \%$ \\
\hline \multicolumn{2}{|c|}{ Total } & 50 & $100 \%$ \\
\hline
\end{tabular}

Table 1. Processed based on the results of the questionnaire 2017

From these data indicate that, still lack of understanding of society about rules of law in effect so that some of parking service business actor utilize it to gain profit and transfer its responsibility. Face-to-face interviews conducted with some of the people who are consumers / users of parking services say that parking service providers often say that our responsibility as a business actor is limited to providing only parking spaces, vehicle security issues when parking is the responsibility of vehicle owners. It can not be justified because Law No. 8/1999 on Consumer Protection in Article 4 letter a, stipulates that consumers are entitled to comfort, safety and safety in consuming goods and / or services. In its technical, PD Parking Makassar Raya employs a parking attendant at every point and parking location. Public roadside parking location for example, the location of the park is the most frequent location in Makassar and is one cause of congestion because it uses the road shoulder as the land. At the location of the parking loss and damage to vehicles experienced parking service users are very frequent. The parking attendant as the person most responsible for the parking location and is an extension of PD Parkir Makassar Raya, when there is a problem often argue that the parking attendant is unlikely to be able to keep all vehicles parked, as for the cost paid by consumers, it is only the cost of rent the land alone is not a security cost. Referring to Regional Regulation of Makassar City Number 17 Year 2006 concerning Management of Public Road Parking In Makassar City Region, in Article 10 letter a, parking lot and parking attendant is required to maintain security, order

\footnotetext{
${ }^{6}$ Aswari, Aan, Andika Prawira Buana, and Farah Syah Rezah. "Harmonisasi Hukum Hak untuk Dilupakan bagi Koran Digital terhadap Calon Mahasiswa di Makassar." Kanun: Jurnal Ilmu Hukum 20.1 (2018): 39-62.
} 
and cleanliness of the parking lot. The article expressly requires the parking attendant to maintain the security of the vehicle, not just guarding the parking location. This also illustrates that the legal awareness must also be built by the perpetrators in this case PD Parkir Makassar Raya and also to the parking attendant itself. Legal awareness of course will be the basis to know the rights and obligations owned by each party, in order to avoid disputes. Based on the spread of the questionnaire online, as many as $70 \%$ of respondents chose the legal path as a settlement of disputes when there is loss and damage of vehicles experienced parking service users. This illustrates the importance of legal awareness as a benchmark, if the legal path is the primary choice when a dispute arises.

\begin{tabular}{|c|c|c|c|}
\hline No. & Answer Category & Frequency & Percentage \\
\hline 1. & legal process & 35 & $70 \%$ \\
2. & Mediation & 15 & $30 \%$ \\
\hline \multicolumn{2}{|c|}{ Total } & 50 & $100 \%$ \\
\hline
\end{tabular}

Tabel 2. Processed based on the results of the questionnaire 2017

The standard clause listed by PD Parkir Makassar Raya on parking tickets issued through APBD Fiscal Year 2017 is one of the forms of absence of legal awareness in the company of the area. Inclusion of the standard clause of course consciously want to divert any form of responsibility to parking service users. Description of the public who became consumers of parking service users who have experienced loss and damage to the vehicle at the time of parking said that parking service business in this case PD Parkir Makassar Raya does not provide a form of liability in accordance with the rules of applicable legislation. PD Parkir Makassar Raya does not provide compensation for loss and damage experienced by parking service users in Makassar. Parties PD Parkir Makasar Raya does not want to compensate for the location of the parking lot where the lost and the destruction of consumer vehicles is not the parking location that is the responsibility and determined PD Parkir Makassar Raya. The parking location is a wild parking location created by radical groups around the site. Of course this is a very preposterous form of statements, where local governments must submit to and obey the rules of the game made by radical groups. The Regional Company is only concerned with the dividend and tariff target parking services to be achieved without regard to the obligations of the company. Based on sources from RAKYATKU.COM, Director of Regional Company (PD) Parkir Makassar Raya, Muh Irianto Ahmad revealed, revenue achievement PD Parkir Makassar Raya 2017 jumped dramatically. In fact, the dividends paid to the City Government (City) municipal budget of 
Makassar amount up to ten times. If previously, in 2015 the company's net revenue of this region is only around $\mathrm{Rp} 9.7$ billion, in 2016 increased to $\mathrm{Rp} 13.7$ billion. "Travel PD Parkir since the end of September 2015 until the end of 2016, our income increased dramatically with an increase of approximately USD 4 billion.As for the net profit obtained in 2015 of Rp 267.6 million, this number continues to soar in 2016 which amounted to Rp 2.36 billion so that the dividends paid in 2017 is also experiencing a drastic increase. If the year 2015 and the dividend is only Rp 147.2 million, for the year 2016 is paid this year is targeted to reach Rp 1.29 billion "We have deposited to the Regional Cash dividend of Rp 1 billion for the second quarter. We are optimistic as soon as possible in this third quarter of the remaining Rp 299 million we deposit all, "he said. ${ }^{7}$

Under the provisions of UUPK, the obligations of the producer (parking service business actor) in Article 7 letter $f$ and $g$, states that:

f). compensate, indemnify and / or reimburse for losses arising from the use, use and utilization of traded goods and / or services;

g). compensate, indemnify and / or reimburse if the goods and / or services received or utilized are not in accordance with the agreement.

The terms is strongly affirming that parking service business actor in this case PD Parking Makassar Raya obliged to provide form of responsibility in accordance with applicable laws and regulations, and eliminating the standard clause listed on the parking ticket PD Parking Makassar Raya should be removed because it is also not appropriate with the provisions of the Law (UUPK).

\section{CONCLUSION}

Based on the above description, with this researcher put forward several things as conclusion, as follows: The form of responsibility of parking service business actors to the consumer protection of parking service users is not effective, it is evident from some interview data to parking service users that the parking service business in this case PD Parkir Makassar Raya does not want to be responsible for the loss and damage of vehicles on parking locations, on the pretext of parking location is not a parking point set PD Parkir Makassar Raya. Parties PD Parkir Makassar Raya also still include a standard callus on parking tickets basically not allowed by the Act. The existence of various problems described above, the researcher gives suggestions as follows: Makassar City Local Government needs to provide direct supervision on policies issued PD Parkir Makassar Raya, and make revisions to the Regional Regulations on Parking Management to be

\footnotetext{
7 Sartika Marzuki, http://news.rakyatku.com/read/59874/2017/08/07/dividen-pd-parkir-makassar-raya-melonjaksepuluh-kali-lipat accessed on 29 November 2017 at 15.31 WITA.
} 
relevant to the provisions of more Legislation high (UUPK). Parking service users are also required to increase legal awareness to know what rights and obligations of service users and parking service business actors.

\section{REFERENCE}

Aswari, Aan, Andika Prawira Buana, and Farah Syah Rezah. "Harmonisasi Hukum Hak untuk Dilupakan bagi Koran Digital terhadap Calon Mahasiswa di Makassar." Kanun: Jurnal Ilmu Hukum 20.1 (2018): 39-62.

M Ravii Marwan, http://news.gunadarma.ac.id/2017/07/mahkamah-agung-kehilangankendaraan-saat-parkir-wajib-diganti-pengelola/, accessed on November 15, 2017 at 16:28 WITA.

Sari, Dwi Tyas Ratna. "Analisis Yuridis Perjanjian Baku Dalam Perjanjian Parkir Yang Dibuatoleh Pt Securindo Packtama Indonesia Di Surabaya." JURNAL NOVUM 1.1 (2013).

Sartika Marzuki, http://news.rakyatku.com/read/59874/2017/08/07/dividen-pd-parkirmakassar-raya-melonjak-sepuluh-kali-lipat accessed on 29 November 2017 at 15.31 WITA.

Satuhu, Rachmanto. "Kendala Dinas Perhubungan dalam Mengawasi dan Memberi Pembinaan Bagi Pengelola Parkir untuk Mencegah Penggunaan Klausa Eksonerasi pada Karcis Parkir (Studi di Dinas Perhubungan Kota Malang)." Kumpulan Jurnal Mahasiswa Fakultas Hukum 1.6 (2013).

Seran, Marcel, and Anna Maria Wahyu Setyowati. "Penggunaan Klausula Eksonerasi Dalam Perjanjian Dan Perlindungan Hukum Bagi Konsumen." Jurnal Hukum Pro Justitia 26.2 (2008).

Wibowo Tunardy, http://www.jurnalhukum.com/pengertian-konsumen/, in access date May 2, 2017 at 10.30 WITA. 